\title{
Aikuiskoulutus ja osaamisen kehittäminen
}

Aikuiskoulutuksesta käytyä keskustelua on pitkään hallinnut kvsvinık senasettelu, jossa verrataan toisiinsa aikuisten ja lasten oppimista. Keskelseksi ongelmaksi on nähty aikuisten saaminen "koulun penkille" sekä niiden vaikeuksien voittaminen, joita aikuisilla lapsiin ja nuoriin verrattuna otaksutaan olevan opiskelussa. Aikuiskoulutuksen tutkimuksessa on etsitty aikuisten oppimisen erityispiirteitä ja kehitetty uutta tieteenalaa, andragogiikkaa (aikuisten kasvatustiede) pedagogiikan (lastenkasvatustieteen । rinnalle. Keskustelua aikuisen oppimisen erityispiirteistä on jo käyty ilman merkittäviä tuloksia niin pitkään, että on aika kysyä koko näkökulman hedelmällisyyttä.

Toisaalta julkisuudessa on käyty keskustelua suomalaisten osaamisesta ja sen kehittämisestä aivan muista lähtökohdista. Maamme kansantalouden ja suomalaisten yritysten kilpailukyvyn on katsottu edellyttävän korkeatasoista osaamista. Osaamisessa ei tällöin kuitenkaan voi olla ensisijassa kysymys yksilöiden tiedoista ja taidoista, vaan osaamisesta yhteiskunnallisena ilmiönä, joka näkyy esimerkiksi teollisuuden tuotteiden kilpailukykyisyytenä, monimutkaisten tuotantoprosessien hallintana ja työn korkeana tuottavuutena. Tällainen osaaminen voi luonnollisesti kehittyä vain yksilöiden oppimisen kautta, mutta se ei silti ole erillisten yksilöiden korkeatasoista osaamista, pelkästään erillisten yksilöiden tietojen ja taitojen summa. Kysymys on useiden henkilöiden osaamisen ja oppimisen yhdistymisestä, tietyn toiminnan hyvästä yhteistoiminnallisesta hallinnasta sekä tähän toimintaan liittyvän korkeatasoisen tradition ja kulttuurin rakentamisesta. Tällaista osaamisen kehittymistä ei voi erottaa työvälineiden parantamisesta, työorganisaation kehittämisestä ja yhteistoiminnan laajentamisesta.

Vaikka aikuiskoulutus on katsottu osaksi kilpailukykypolitiikkaa, ei huoli kilpailukyvystä ja suomalaisten osaamisen kansainvälisestä tasosta ole johtanut aikuiskoulutuksen instituutioiden voimakkaaseen kehittymiseen. Päin vastoin, monilla viime vuosikymmenellä nousukautta eläneistä työelämän koulutus- ja kurssikeskuksista on vaikeuksia, ja perinteiset kansansivistyslaitoksetkin etsivät uutta toiminta-ajatusta. Tuntuu siltä kuin aikuiskoulutuksen nykyisillä laitoksilla ei uskottaisi olevan merkittävää roolia uuden osaamisen kehittämisessä. Ovatko aikuiskoulutuksen ammattilaiset syrjässä keskustelusta silloin, kun on kysymys osaamisen kehittämisestä kansallisella tasolla?

Yksi syy siihen, etteivät aikuiskoulutuksen laitokset ole olleet näkyvästi esillä siellä, missä luodaan uutta osaamista, on ehkä ollut alalle ominainen tapa tarkastella oppimista. Oppiminen on nähty kapeasti vain yksilöiden oppimisena, jota lisäksi on tarkasteltu kouluoppimisen ja perinteisen opetuksen kannalta. Tämän näkökulman ulkopuolelle jää tietyn toiminnan yhteistoiminnallisen hallinnan kehittäminen. Kouluoppimisen perinteinen malli lähtee valmiin - usein jopa pysähtyneen ja toiminnallisista yhteyksistään irroitetun tiedon omaksumisesta. Siihen ei sisälly annetun tiedon ja vallitsevien käytäntöjen ylittäminen, yhteiskunnaliisesti uuden luominen. 
Yhteiskunnallisesti uuden on katsottu syntyvän aikuiskoulutuksen ulkopuolella ja vain luovan uusia yksilöllisiä "koulutustarpeita".

Yhteiskunnallisen oppimisen ja yksilöllisen oppimisen jyrkkä erottaminen toisistaan ei enää ole perusteltavissa. Yhteiskunnan eri toimintojen kehittymisen nopeus on yhä enemmän sidoksissa juuri yhteisön oppimisen ja yksilöiden oppimisen vuorovaikutukseen. Minkä tahansa merkittävän keksinnön soveltaminen tai uuden välineen käyttöönotto edellyttää lukemattomia pieneripiä keksintöjä ja oivalluksia, jotka vasta yhdessä määräävät yhteiskunnan tasolla osaamisen kehitysvauhdin. Korkeaa kansainvälistä tasoa oleva tuotannollinen osaaminen ei voi perustua yksittäisiin huippukykyihin, vaan oppimisen ja ongelmanratkaisun laajuuteen.

Aikuiskoulutustoiminta, joka pitäytyy kouluoppimisen malliin, jää väistämättä yhä kauemmaksi osaamisen kehityksen kärjestä. Jotta näin ei tapahtuisi, aikuiskoulutuslaitosten tulisi olla mukana uuden osaamisen luomisessa.

Tässä Aikuiskasvatus -lehden numerossa käsitellään osaamista ja oppimista yhteiskunnallisina ilmiöinä. Pertti Huttusen artikkeli tuo kiinnostavalla tavalla esiin sen, miten juuri yhteisönä oppiminen on ihmislajin erityispiirre ja miten osaamista ylläpitävien ja kehittävien yhteisöjen luonne samoin kuin yhteisön oppimisen mekanismit ovat historian kuluessa muuttuneet. Raimo Lovio analysoi tämän päivän tuotannollisen oppimisen ja teknisen kehityksen mekanismeja. Hänen artikkelinsa antaa viitteitä siitä, mitkä ovat tänä päivänä osaamisen kehittymisen kannalta keskeisiä yhteisöjä. Sellaisia näyttää syntyvän, kun eri aloilla tieteellisen tutkimuksen, välineiden valmistuksen ja välineitä käyttävän toiminnan välille rakentuu kestävä vuorovaikutus. Tämä tieto antaa viitteitä siitä, millaisista yhteistoimintasuhteista aikuiskoulutus voisi löytää roolinsa uuden osaamisen kehittämisessä.

Osaamisen kehittyminen on yhä olennaisemmin sidoksissa tieteen ja käytännön väliseen vuorovaikutukseen. Tieteen tehtävä tässä vuorovaikutuksessa ei ole vain uusien käytäntöä palvelevien valmiiden välineiden ja apuneuvojen tuottaminen, vaan yhä enemmän sellaisten selittävien mallien ja ajattelun välineiden tuottaminen, joilla voidaan ratkaista monia ongelmia ja tehostaa käytännössä tapahtuvaa oppimista. Tieteestä tiedottaminen ja tiedekasvatuksen suuri ongelma onkin yleisön katseen kiinnittäminen tieteen yksittäisistä, näyttävistä sovelluksista tieteellisen ajattelun kehitykseen, tieteellisiin selityksiin ja tieteelliseen maailmankuvaan. Erityisen suuri vaikeus tämä lienee tieteen esineellisiä välineitä ja tuloksia esiin tuovan uuden kansansivistyslaitoksen, Tiedekeskuksen toiminnassa, jonka roolia Jarkko Hautamäki käsittelee artikkelissaan.

Huomion kiinnittäminen uuden osaamisen kehittymisen yhteiskunnallisiin mekanismeihin asettaa aikuiskoulutuksen laitoksille vastattavaksi kaksi kysymystä. Ensinnäkin on kysyttävä, miten nämä laitokset voisivat olla nykyistä tiiviimmin mukana niissä yhteistoiminnan ja vuorovaikutuksen verkostoissa, joissa yhteiskunnallisesti uusi osaaminen kehittyy ja mitä näille instituutioille tapahtuu, jos ne eivät löydä paikkaa tässä yhteistoiminnassa. Toiseksi on kysyttävä, millaisia uusia teoreettisia ja käytännöllisiä välineitä aikuiskouluttajat tarvitsevat voidakseen antaa myönteisen panoksen tällaisessa yhteistoiminnassa sekä voidakseen ylittää sen kaksijakoisuuden, joka tällä hetkellä vallitsee yksilön oppimisen ja yhteisön osaamisen kehittymisen välillä niin oppimisen teoriassa kuin aikuiskoulutuksen käytännössäkin. Yrjö Engeströmin väitöskirjassaan esittämä ekspansiivisen oppimisen teoria ja siihen perustuva uusi kehittämisen metodiikka on merkittävä askel tarvittavan uuden ajattelutavan ja välineistön kehittämisessä. Julkaisemme tässä numerossa käännökset väittelijän väitöstilaisuudessa pitämästä lectio precursoriasta ja vastaväittäjän lausunnosta. 